$$
\begin{aligned}
& \text { TRIP 型ベイニティックフェライト鋼の疲労特性に及ぼす } \\
& \text { 微粒子ピーニングの影響 } \\
& \text { 名取 昌弘* 水野 悠太* 宋 星武** 杉本 公一** }
\end{aligned}
$$

\title{
Effects of Fine Particle Peening on Fatigue Properties of TRIP-Aided Bainitic Ferrite Steel
}

by

\author{
Masahiro Natori*, Yuta Mizuno*, Sung-moo Song** and Koh-ichi Sugimoto**
}

The effects of fine particle peening on the fatigue properties of transformation-induced plasticity (TRIP)-aided bainitic ferrite steel were investigated for applications to precision gears. Fine particle peening increased the fatigue limit and lowered the notch-sensitivity in the TRIP-aided bainitic ferrite (TBF) steel, compared with SNCM420 steel. In the stress intensity range of less than $25 \mathrm{MPa} \mathrm{m}{ }^{1 / 2}$, TBF steel subjected to fine particle peening exhibited a larger threshold value of the stress intensity range and higher crack propagation rate than SNCM420 steel. The increased fatigue properties are principally associated with (1) higher Vickers hardness, (2) higher compressive residual stress and (3) plastic relaxation resulting from the strain-induced transformation of metastable retained austenite in a surface hardening layer, which may suppress fatigue crack initiation and propagation.

\section{Key words:}

Fatigue strength, Fine particle peening, Retained austenite, Residual stress,

TRIP-aided steel

\section{1 緒言}

近年，変速機駆動用精密歯車には軽量・コンパクト化 の要望が強い ${ }^{1)}$.一般に, このような歯車部品は低合金 構造用鋼を冷間鍛造または熱間鍛造，切削・研削加工な ごの後 ${ }^{2)}$, またはさらに浸炭処理 ${ }^{3) \sim 8)}$ や浸炭窒化処理後 9) にショットピーニング 2) 51,9) または微粒子ピーニング

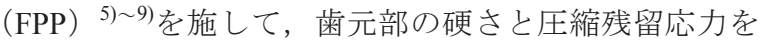
高めることによって疲労強度を高めている，浸炭処理を 施さない前者に関しては, 母材のビッカース硬さが 375HV を超える範囲においては硬さを増加させても疲

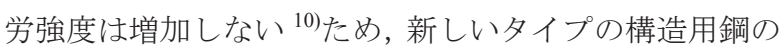
開発が期待されている.

次世代の構造用鋼として期待されている準安定な残 留オーステナイト $\left(\gamma_{\mathrm{R}}\right)$ の変態誘起塑性（TRIP）を利用 した TRIP 型ベイニティックフェライト (TBF) 鋼は高 い切欠き疲労強度 ${ }^{10)}$ と衝撃じん性 ${ }^{11)}$ を有する。また, FPP 処理を受けると, 浸炭鋼 ${ }^{3) \sim 99}$ や浸炭窒化鋼 9) と同様 に数\% 10 数 $\mathrm{vol} \%$ $\gamma_{\mathrm{R}}$ がひずみ誘起マルテンサイト変 態し, それにともなう体積澎張によって, 表面層の硬さ と圧縮残留応力が増加寸ることが報告されている ${ }^{12)}$. こ れらの優れた表面硬化特性より, FPP 処理は TBF 鋼の 疲労強度を増加させることが期待できる.

そこで本研究は, $\mathrm{TBF}$ 鋼を変速機の駆動用歯車に適用 して高疲労強度化（高トルク化）を図ることを目的とし
て, $\mathrm{TBF}$ 鋼の平滑材と切久き材の疲労強度特性に及ぼす FPP 処理の影響を調查した. また, それらの結果と表面 硬化層特性（硬さ，残留応力など）および $\gamma_{\mathrm{R}}$ のひずみ誘 起変態挙動との関係について検討した.

\section{2 実験方法}

\section{$2 \cdot 1$ 供試鋼の熱処理条件}

TBF 鋼の供試鋼には，Table 1 の化学組成を有する熱間 圧延丸棒鋼（直径 $13 \mathrm{~mm}$, 真空溶製）を用いた。この棒鋼 から圧延方向に平行に Fig. 1 に示寸寸法の引張試験と疲 労試験用の平滑材と切久き材を作製した. 切久き材の応 力集中係数はいずれも 1.9 とした。 これらの試験片を $900^{\circ} \mathrm{C}$ でオーステナイト化後, $375^{\circ} \mathrm{C}$ で $1000 \mathrm{~s}$ の等温変態処 理を施し, TBF 鋼を製造した (Fig. 2(a))．この等温変態 処理温度はマルテンサイト変態開始温度 $\left(M_{\mathrm{S}}\right)$ と終了温 度 $\left(M_{\mathrm{f}}\right)$ の間にあり, 最良の延性・じん性バランスを与 える温度に相当する ${ }^{10), 11)}$. 比較のため, 市販の SNCM420

\begin{tabular}{|c|c|c|c|c|c|c|c|}
\hline Steel & $\mathrm{C}$ & $\mathrm{Si}$ & Mn & $\mathrm{P}$ & S & $\mathrm{Cr}$ & Mo \\
\hline TBF & 0.20 & 1.50 & 1.51 & 0.005 & 0.002 & 1.00 & 0.01 \\
\hline SNCM420 & 0.20 & 0.20 & 0.50 & 0.009 & 0.013 & 0.55 & 0.15 \\
\hline Steel & $\mathrm{Ni}$ & $\mathrm{Al}$ & $\mathrm{Nb}$ & $\mathrm{N}$ & Ms & $\mathrm{M}_{\mathrm{f}}$ & \\
\hline TBF & 0.02 & 0.039 & 0.05 & 0.0009 & 400 & 238 & \\
\hline SNCM420 & 1.68 & - & - & - & 418 & - & \\
\hline
\end{tabular}

Table 1 Chemical composition (mass\%) and martensite-start and -finish temperatures $\left(M \mathrm{~s}, M_{\mathrm{f}},{ }^{\circ} \mathrm{C}\right)$ of the steels used.

$\dagger$ 原稿受理 平成26年6月10日 Received June 10, 2014 @2015 The Society of Materials Science, Japan

* 信州大学大学院理工学系研究科 干 380-7553 長野市若里

Graduate School, Shinshu Univ., Wakasato, Nagano 380-8553.

** 正会員 信州大学学術研究院工学系 干380-8553 長野市若里

Inst. of Eng., Academic Assembly, Shinshu Univ., Wakasato Nagaano 380-8553. 
(a)

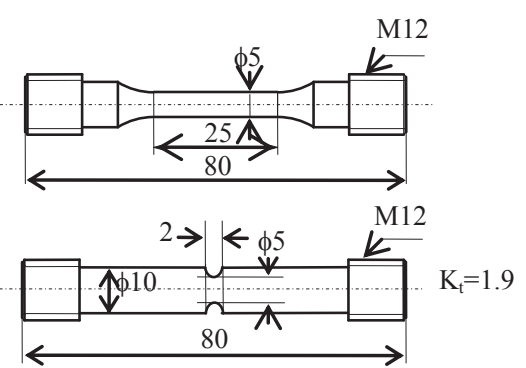

(c)

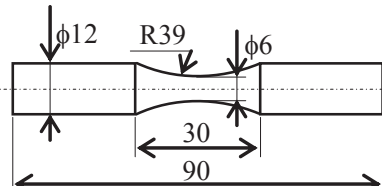

(d)

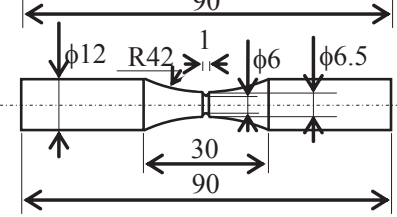

$\mathrm{K}_{\mathrm{t}}=1.9$

Fig. 1 Dimensions of smooth and notched specimens for $(a, b)$ tensile and (c, d) fatigue tests. The notch root radii of (b) and (d) are 1 and $0.5 \mathrm{~mm}$, respectively.

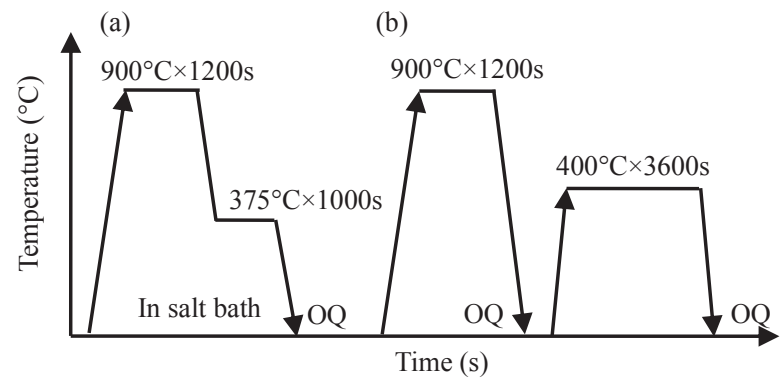

Fig. 2 Heat treatment diagrams of (a) TBF and (b) SNCM420 steels, in which "OQ" represents quenching in oil.

鋼（Table 1）を用い，Fig. 2(b)の調質処理を施した。こ のとき, SNCM420 鋼の硬さを $\mathrm{TBF}$ 鋼と等しくするため, 焼戻し温度は $400^{\circ} \mathrm{C}$ とた（保持時間 $3600 \mathrm{~s}$ )。

\section{$2 \cdot 2$ 微粒子ピーニング処理条件}

熱処理後の試験片表面をエメリー紙で\#1200 まで研磨 後, 電解研磨で加工層を $50 \mu \mathrm{m}$ 除去したのち, Table 2 に 示寸条件で電解研磨面に FPP 処理を施した. 投射方式は エアノズル式とした.

Table 2 Fine particle peening conditions.

\begin{tabular}{c|c}
\hline Material & Steel ball \\
\hline Shot diameter $(\mu \mathrm{m})$ & 70 \\
\hline Pressure $(\mathrm{MPa})$ & 0.26 \\
\hline Peening time $(\mathrm{s})$ & 30 \\
\hline Arc height $(\mathrm{mm}[\mathrm{N}])$ & 0.104 \\
\hline Coverage $(\%)$ & 300 \\
\hline
\end{tabular}

\section{$2 \cdot 3$ 組織観察と表面粗さ, $\gamma_{\mathrm{R}}$ 特性, 硬さ, $\mathrm{X}$ 線残} 留応力測定

組織観察には光学顕微鏡, 電界放出形走査電子顕微鏡 (FE-SEM，日本電子製 JSM-7000F）および電子線後方散 乱回折装置（EBSD，テクセムラボラトリー製 OIM シス
テム)を用いた. 表面粗さの測定にはレーザー顕微鏡 (キ 一エンス製 VK-8510）を用い，最大高さ $R \mathrm{z}$ を求めた。

$\gamma_{\mathrm{R}}$ の体積率 $\left(f_{\gamma}\right)$ は X 線回折法 $\left(5\right.$ ピーク法 ${ }^{13)}$, Mo-K $\alpha$ 線）により測定した。 $\gamma_{\mathrm{R}}$ の炭素濃度 $\left(C_{\gamma}\right)$ はX線回折法 $(\mathrm{Cu}-\mathrm{K} \alpha$ 線 $)$ によって測定した $\mathrm{Fe}-\gamma(\mathrm{fcc})$ 相の格子定数 $a_{\gamma}\left(\times 10^{-1} \mathrm{~nm}\right)$ を次式 ${ }^{14)}$ に代入することによって計算した.

$C_{\gamma}=\left\{a_{\gamma}-3.578-0.00095 \times\left(\% M n_{\gamma}\right)-0.0006 \times\left(\% C r_{\gamma}\right)-\right.$ $\left.0.022 \times\left(\% N_{\gamma}\right)-0.0056 \times\left(\% A l_{\gamma}\right)-0.0031 \times\left(\% M o_{\gamma}\right)\right\} / 0.0330$

ここで，\%Mn $n_{\gamma} \% C r_{\gamma} ％ N_{\gamma}, \% A l_{\gamma} ％ M o_{\gamma}$ はそれぞれの 元素の $\gamma_{\mathrm{R}}$ 中の固溶濃度である. 本研究では, 便宜上, そ れぞれの元素の添加量を用いた.

硬度測定には微小ビッカース硬度計（島津製作所社製, HMV-1）を用い, 荷重 $0.49 \mathrm{~N}$, 保持時間 $30 \mathrm{~s}$ で微粒子ピ ーニング面から深さ方向の硬さを測定した.

$\mathrm{X}$ 線応力測定には湾曲 IPX線回折装置（リガク製, RINT RAPID）を使用した。測定には $\sin ^{2} \psi$ 並傾法 ${ }^{15)}$ を用 い, Table 3 に示寸条件で圧延方向の Fe- $\alpha(\mathrm{bcc})$ 相の残留応 力 $\sigma_{\mathrm{X} \alpha}$ を測定した. 残留応力の計算には次の式を用いた.

$$
\sigma_{\mathrm{X} \alpha}=-\{E / 2(1+v)\} \cot \theta_{0}\left(\partial 2 \theta / \partial \sin ^{2} \psi\right)
$$

ここで，E，怰ヤン゙率とポアソン比である.また， $\theta_{0}$, 日はそれぞれ無ひずみ状態, ひずみ状態での回折角, $\psi$ は 回折面法線と試料面法線のなす角である. なお, 深さ方 向への残留応力分布を測定するため, 材料表面を逐次電 解研磨により除去して測定を行った．また，本研究では 残留応力測定には表面除去による応力の解放を考慮し なかった。

\section{$2 \cdot 4$ 引張試験と疲労試験}

引張試験には万能引張試験機（島津製作所製 G-10TD） を用い，クロスヘッド速度 $1 \mathrm{~mm} / \mathrm{min}$, 試験温度 $20^{\circ} \mathrm{C}$ で 試験を行った。疲労試験には小野式回転曲げ疲労試験機

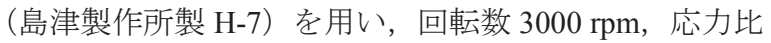
$R=-1$, 試験温度 $20^{\circ} \mathrm{C}$ で試験を行った，疲労試験時の 表面き裂の発生・進展挙動は, 試験を逐次中断し,

FE-SEM を用いて観察した。疲労き裂の長さは, Fig. 1(c) の試験片表面に直径 $\phi 0.1 \mathrm{~mm}$, 深さ $0.1 \mathrm{~mm}$ の微小孔を加 工した試験片を使用し，レプリカ法を用いて測定した。

Table 3 X-ray measuring conditions of residual stress and material constants.

\begin{tabular}{c|c|c}
\hline Phase & $\mathrm{Fe}-\alpha(\mathrm{bcc})$ & $\mathrm{Fe}-\gamma(\mathrm{fcc})$ \\
\hline Characteristic X-ray & \multicolumn{2}{|c}{$\mathrm{Cr}-\mathrm{K} \alpha$} \\
\hline Voltage, current & \multicolumn{2}{|c}{$40 \mathrm{kV}, 30 \mathrm{~mA}$} \\
\hline Collimator diameter & \multicolumn{2}{|c}{$\phi 0.8 \mathrm{~mm}$} \\
\hline$\psi$ & $10^{\circ}, 23^{\circ}, 31^{\circ}, 38^{\circ}, 45^{\circ}$ \\
\hline Diffraction plane & $(211)$ & $(220)$ \\
\hline Young's modulus & $223 \mathrm{GPa}$ & $192 \mathrm{GPa}$ \\
\hline Poisson's ratio & \multicolumn{2}{|c}{0.28} \\
\hline Stress constant & $-324 \mathrm{MPa} / \mathrm{deg}$ & $-621 \mathrm{MPa} / \mathrm{deg}$ \\
\hline
\end{tabular}




\section{3 実験結果}

\section{$3 \cdot 1$ 熱処理まま材の組織と引張特性}

Fig. 3 に熱処理ままの TBF 鋼と SNCM420 鋼の組織の EBSD 解析結果を示す. また, Table 4 にそれらの鋼の $\gamma_{\mathrm{R}}$ 相の初期体積率 $\left(f_{\gamma 0}\right)$ と炭素濃度 $\left(C_{\gamma 0}\right)$ ， MA 相体積率 $\left(f_{\mathrm{MA}}\right)$, 炭化物体積率 $\left(f_{\theta}\right)$ を示す. 先の報告 ${ }^{10)}$ と同様に, TBF 鋼の母相組織は主にベイニティックフェライトで あり，これに少量の軟質マルテンサイト $\left(\alpha_{\mathrm{m}}\right)$ が存在す る混合組織である。第 2 相として, 微細な $\gamma_{\mathrm{R}}$ 相および硬 質マルテンサイト $\left(\alpha_{\mathrm{m}}{ }^{*}\right)$ と $\gamma_{\mathrm{R}}$ の混合相（MA 相と呼ば れる）がそれぞれベイニティックフェライトのラス境界, 旧オーステナイト粒界やパケット境界に存在していた。 母相中には炭化物は存在しなかった. Yoshikawa $5^{10)}$ と 同様に, SEM 像と Fig. 3(a)の image quality (IQ) map の比 較をしたところ, Fig. 3(a)の黄緑色の相が MA 相に相当 した.この時の MA 相の IQ index は 4650 以下に対応 し，その体積率は $12.4 \mathrm{vol} \%$ であった。

SNCM420 鋼は一般的な焼戻しマルテンサイト組織で あり，軟質マルテンサイト中には微細な炭化物（セメン タイト）が存在し，その体積率は約 5 vol\%であった。ま

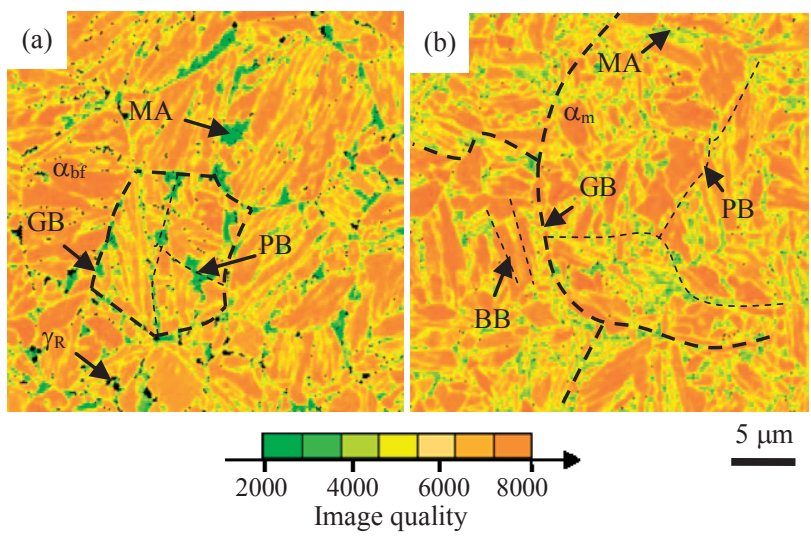

Fig. 3 Image quality distribution maps of $\mathrm{Fe}-\alpha(\mathrm{bcc})$ in as-heat treated (a) TBF and (b) SNCM420 steels, in which orange, green (or yellowish green) and black regions represent bainitic ferrite $\left(\alpha_{\mathrm{bf}}\right)$ (or soft wide lath-martensite $\left.\left(\alpha_{\mathrm{m}}\right)\right)$, MA phase, and retained austenite $\left(\gamma_{\mathrm{R}}\right)$, respectively. GB, $\mathrm{PB}$ and $\mathrm{BB}$ are prior austenitic grain, packet and block boundaries, respectively.

Table 4 Retained austenite characteristics, tensile properties and hardness of as-heat treated TBF and SNCM420 steels.

\begin{tabular}{c|cccc|cc}
\hline Steel & $\mathrm{f}_{\gamma 0}$ & $\mathrm{C}_{\gamma 0}$ & $\mathrm{f}_{\mathrm{MA}}$ & $\mathrm{f}_{\theta}$ & $\mathrm{YS}$ & $\mathrm{TS}$ \\
\hline TBF & 11.9 & 0.69 & 12.4 & 0.00 & 1071 & 1350 \\
\hline SNCM420 & 0.3 & - & 11.4 & 5.14 & 1186 & 1228 \\
\hline \multicolumn{1}{|c}{} \\
\hline Steel & YR & UEl & TEl & $\mathrm{TS}_{\mathrm{N}}$ & NSR & HV $_{0}$ \\
\hline TBF & 0.79 & 6.2 & 18.1 & 1952 & 1.45 & 377 \\
\hline SNCM420 & 0.97 & 2.5 & 12.5 & 1894 & 1.54 & 373 \\
\hline
\end{tabular}

$f \gamma_{0}$ (vol\%): volume fraction of retained austenite, $C \gamma_{0}(\operatorname{mass} \%)$ carbon concentration of retained austenite, $f_{\mathrm{MA}}(\mathrm{vol} \%)$ : volume fraction of the MA phase, $f_{\theta}$ (vol \%): volume fraction of carbides, $Y S(\mathrm{MPa})$ : yield stress, TS $(\mathrm{MPa})$ : tensile strength, YR: yield ratio (= $Y S / T S), U E l(\%)$ : uniform elongation, TEl (\%): total elongation, $T S_{\mathrm{N}}$ $(\mathrm{MPa})$ : notch tensile strength, $N S R\left(=T S_{\mathrm{N}} / T S\right)$ : notch strength ratio, $H V_{0}$ : original Vickers hardness.
た，TBF 鋼と同様に IQ index が 4650 以下の相が MA 相 であると仮定したときの MA相体積率は $11.4 \mathrm{vol} \%$ であっ た。この体積率は $\mathrm{TBF}$ 鋼とほぼ等しいが，旧オーステナ イト粒径は TBF 鋼より大きい特徵を有した（Fig. 3）.

Fig. 4 に熱処理状態の TBF 鋼と SNCM420 鋼の平滑材 と切欠き材を引張試験した時の公称応力一公称ひずみ $(\sigma-\varepsilon)$ 曲線と公称応力一変位 $(\sigma-\delta)$ 曲線を示す。 そ れらの鋼の熱処理状態の引張特性と初期硬さ $\left(H V_{0}\right)$ を Table 4 に示す. 平滑材では, TBF 鋼は SNCM 420 鋼に比 較して，変形初期の変形応力は低いが，その後のひずみ 硬化率が大きく, 結果的に低い $0.2 \%$ 耐力 $(Y S)$, 高い引 張強さ $(T S)$ と大きな一様伸び $(U E l)$ と全伸び $(T E l)$ を示した，一方，切欠き材についてみると， $\mathrm{TBF}$ 鋼の切 欠き引張強さ $\left(T S_{\mathrm{N}}\right)$ と破断伸びも従来の研究 ${ }^{10), 11)}$ と同 様に SNCM420 鋼より高かった（Fig. 4(b)）。また, Table 4 に示すように, $\mathrm{TBF}$ 鋼の切欠き強度比 $\left(N S R=T S_{\mathrm{N}} / T S\right)$ は SNCM420 鋼より低い值を示した。

\section{$3 \cdot 2$ 表面硬化層の組織，硬さ分布， $\gamma_{\mathrm{R}}$ 体積率分布 之残留応力分布}

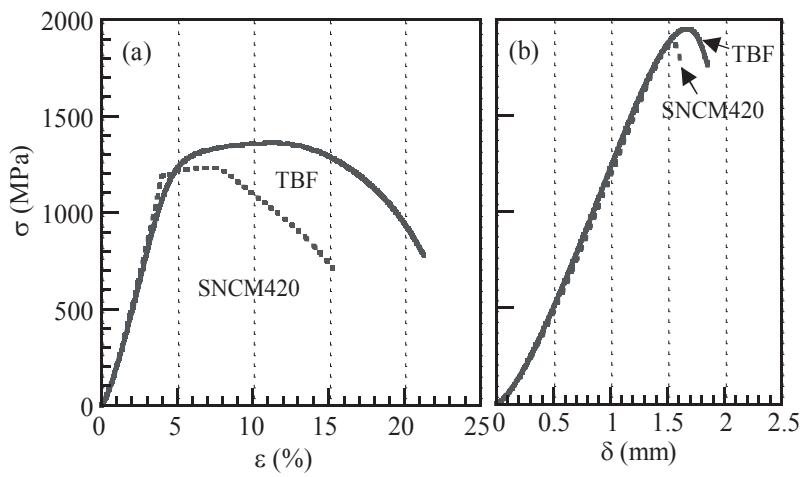

Fig. 4 (a) Nominal stress - strain $(\sigma-\varepsilon)$ curves of smooth specimens and (b) nominal stress-displacement $(\sigma-\delta)$ curves of notched specimens of as-heat treated TBF and SNCM420 steels.
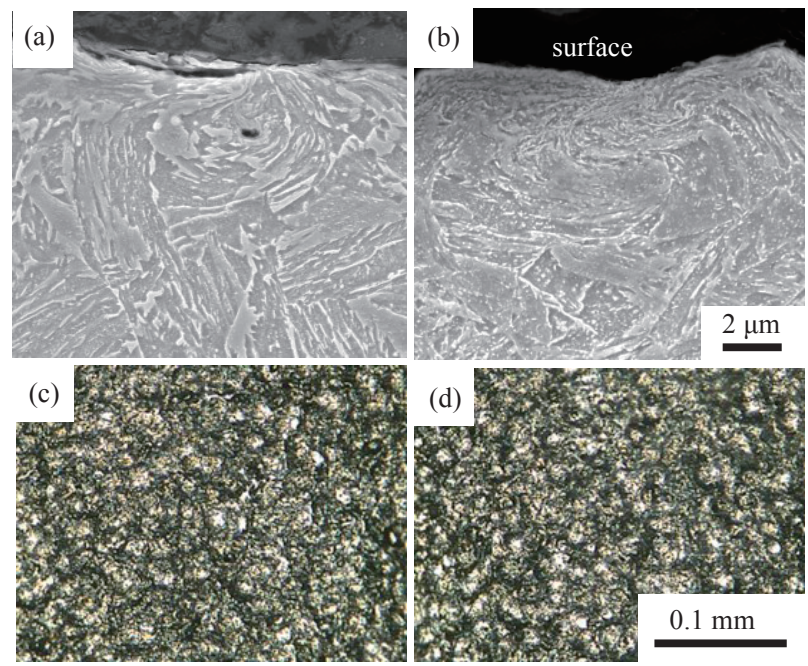

$\mathrm{Rz}=3.59 \mu \mathrm{m}$

$\mathrm{Rz}=3.85 \mu \mathrm{m}$

Fig. 5 (a, b) SEM images of surface hardened layers and (c, d) optical micrographs of the surfaces of $(a, c)$ TBF and $(b, d)$ SNCM420 steels subjected to fine particle peening. $R \mathrm{z}$ is maximum height roughness. 
Fig. 5 に FPP 処理後の TBF 鋼と SNCM420 鋼の表面硬 化層縦断面の SEM 像と表面の光学顕微鏡写真を示す. いずれの鋼においても，表面から約 2〜 $5 \mu \mathrm{m}$ においてと くに大きな塑性変形を受けていることがわかる。また， TBF 鋼は SNCM 420 鋼に比較して表面粗さが小さくなる 傾向が認められた。

Fig. 6 に FPP 処理後の TBF 鋼と SNCM420 鋼の表面硬 化層の硬さの分布と $\gamma_{\mathrm{R}}$ 体積率の分布を示す. TBF 鋼の FPP 処理後の表面硬化層の最大硬さと深さは，それぞれ

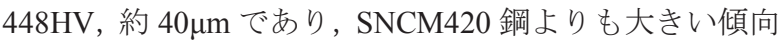
にあった。 FPP 処理を施した TBF 鋼の表面硬化層の $\gamma_{\mathrm{R}}$ の体積率分布をみると（Fig. 6(b)），表面から深さ $30 \mu \mathrm{m}$ までの範囲で $\gamma_{\mathrm{R}}$ のひずみ誘起マルテンサイト変態が生 じた.このとき，表面では， $\gamma_{\mathrm{R}}$ のほとんどがマルテンサ
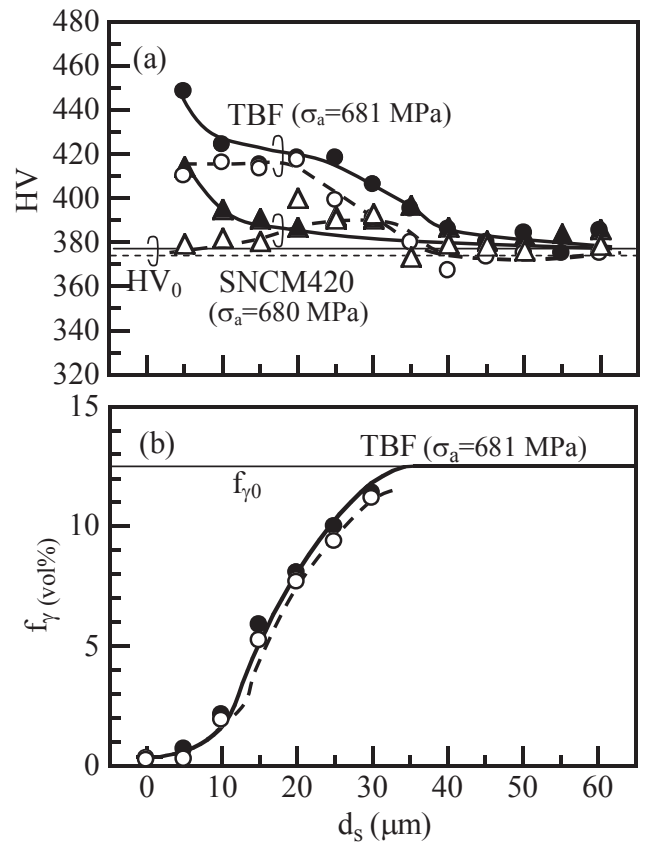

Fig. 6 Variations in (a) Vickers hardness $(H V)$ and (b) volume fraction of retained austenite $\left(f_{\gamma}\right)$ of TBF $(\bullet \circ)$ and SNCM420 $(\boldsymbol{\Delta} \Delta)$ steels subjected to fine particle peening as a function of depth from the surface $\left(d_{\mathrm{S}}\right)$. Solid and open symbols represent experimental values before and after the fatigue tests, respectively.

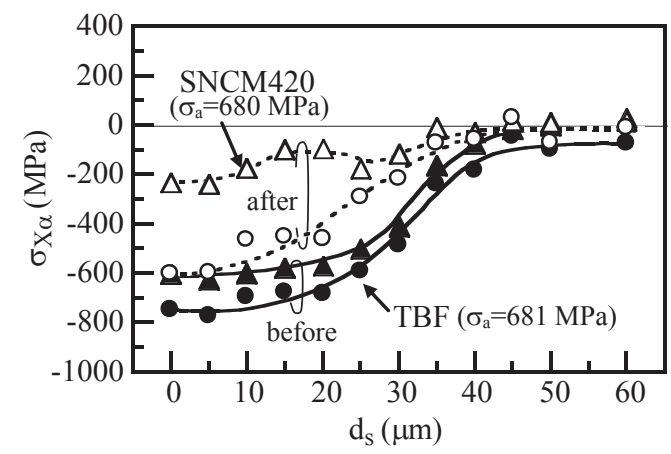

Fig. 7 Variations in X-ray residual stress $\left(\sigma_{\mathrm{X} \alpha}\right)$ of $\mathrm{Fe}-\alpha(\mathrm{bcc})$ in smooth specimens of TBF $(\bullet \circ)$ and SNCM420 $(\Delta \Delta)$ steels subjected to fine particle peening as a function of depth from the surface $\left(d_{\mathrm{S}}\right)$. Solid and open symbols represent X-ray residual stresses before and after the fatigue test, respectively.
イトに変態していた．表面の硬さの測定は難しいので, 以下では，便宜上，表面から $10 \mu \mathrm{m}$ 内部の硬さを表面硬 さ $H V_{\mathrm{S}}$ と呼ぶ.

Fig. 7 に FPP 処理後の TBF 鋼と SNCM420 鋼の表面硬 化層の $\mathrm{Fe}-\alpha(\mathrm{bcc})$ 相の残留応力分布を示す. 名取らの報告 12) と同様に, $\mathrm{TBF}$ 鋼の圧縮残留応力は $\mathrm{SNCM} 420$ 鋼より 高く，その差は最大で $200 \mathrm{MPa}$ 程度であった。

\section{$3 \cdot 3 \quad \mathrm{~S}-\mathrm{N}$ 曲線と疲労限}

Fig. 8 に各鋼の平滑材と切欠き材の FPP 未処理材およ び FPP 処理材の $\mathrm{S}-\mathrm{N}$ 曲線をそれぞれ示す。以下では, 平滑材と切欠き材の疲労限をそれぞれ $F L, F L_{\mathrm{N}}$ で示す. 平滑材において, TBF 鋼は FPP 未処理材, FPP 処理材と もに SNCM420 鋼よりも高い疲労限を示した. FPP 未処 理材の疲労限に対する FPP 処理による疲労限の増加量 の割合 (増加率) を比較すると, TBF 鋼, SNCM420 鋼 でそれぞれ 30\%，29\%でほぼ同程度であった。一方，切 欠き材においては，未処理材の場合は $\mathrm{TBF}$ 鋼と SNCM420 鋼の間で疲労限の差はほとんど認められない が，FPP 処理材では，TBF 鋼の疲労限は SNCM420 鋼に 比較して大きく増加した。この場合の疲労限の増加率は TBF 鋼，SNCM420 鋼でそれぞれ 51\%，29\%であり，TBF 鋼では平滑材よりも増加率は大きくなった．疲労寿命も 同様な傾向が表れた，疲労破壊は平滑材，切欠き材のい ずれの場合も表面き裂型の破壊であった。

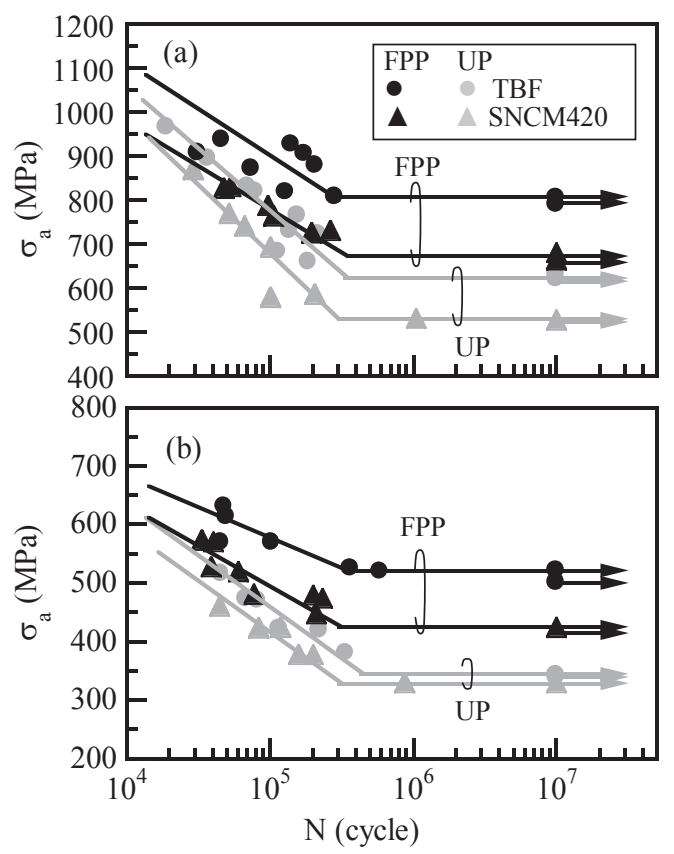

Fig. 8 Stress amplitude-number of cycles to failure $\left(\sigma_{\mathrm{a}}-N\right)$ curves of (a) smooth and (b) notched specimens of TBF and SNCM420 steels. Black and gray marks and lines represent the samples after fine particle peening (FPP) and without peening (unpeened, UP), respectively.

Fig. 9 に各鋼の平滑材と切欠き材の FPP未処理材およ びFPP 処理材の疲労限と硬さ（初期硬さ $H V_{0}$, FPP 処理 
後の表面硬さ $H V_{\mathrm{S}}$ ）との関係を示す。調質処理を施した 既存の低合金構造用鋼では，ビッカース硬さと平滑材の 疲労限の関係は $F L=1.55 H V_{0}\left(H V_{0} \leq 400\right)$ に従うことが 報告されている ${ }^{16)}$. 本研究の FPP 処理を施していない $\mathrm{TBF}$ 鋼の疲労限は $F L=1.55 H V_{0}$ の直線にほぼ一致したが, SNCM420 鋼では直線より低い側に位置した。一方, FPP 処理後の表面硬さと平滑材および切欠き材の疲労限と の関係は $\mathrm{TBF}$ 鋼において，それぞれ $F L=1.78 H V_{\mathrm{S}}, F L_{\mathrm{N}}=$ $1.11 H V_{\mathrm{S}}$ となった.

Table 5 に TBF 鋼, SNCM420 鋼の FPP 未処理材と FPP 処理材の切欠き材の切欠き感受性を示す。切欠き感 受性 $(q)$ は次式 ${ }^{17)}$ で定義した.

$$
q=\left\{\left(F L / F L_{\mathrm{N}}\right)-1\right\} /\left(K_{\mathrm{t}}-1\right)
$$

ここで， $K_{\mathrm{t}}$ は応力集中係数である. Table 5 より, FPP 処 理を施した場合において，TBF 鋼の切欠き感受性は

SNCM420 鋼より少し低いことがわかる.

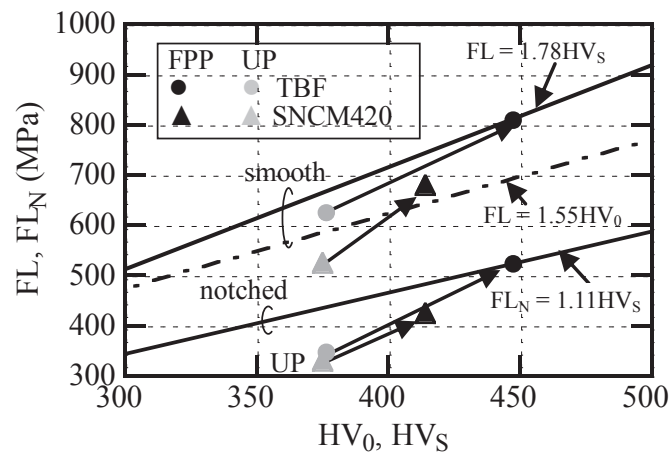

Fig. 9 Relationships between fatigue limits of smooth and notched specimens $\left(F L, F L_{\mathrm{N}}\right)$ and hardness of the original and fine particle peened surface $\left(H V_{0}, H V_{\mathrm{S}}\right)$ in TBF and SNCM420 steels. Black and gray marks represent fine particle peening (FPP) and no peening (unpeened, UP), respectively.

Table 5 Fatigue properties of TBF and SNCM420 steels.

\begin{tabular}{c|ccc|ccc}
\hline & \multicolumn{3}{|c|}{ Unpeening } & \multicolumn{3}{c}{ Fine particle peening } \\
\hline Steel & $\mathrm{FL}$ & $\mathrm{FL}_{\mathrm{N}}$ & $\mathrm{q}$ & $\mathrm{FL}$ & $\mathrm{FL}_{\mathrm{N}}$ & $\mathrm{q}$ \\
\hline TBF & 622 & 344 & 0.90 & 806 & 520 & 0.61 \\
\hline SNCM420 & 526 & 330 & 0.66 & 680 & 425 & 0.67 \\
\hline
\end{tabular}

$F L, F L_{\mathrm{N}}(\mathrm{MPa})$ : fatigue limits of smooth and notched specimens, respectively, $q$ : notch sensitivity factor $\left[q=\left\{\left(F L / F L_{\mathrm{N}}\right)-1\right\} /\left(K_{\mathrm{t}}-1\right)\right]$.

\section{$3 \cdot 4$ 疲労変形後の表面硬化層特性の変化}

疲労限以下の応力振幅 $\left(\sigma_{\mathrm{a}}\right)$ で $10^{7}$ サイクル疲労試験 後の平滑材の表面硬化層の硬さ分布と $\gamma_{\mathrm{R}}$ 体積率分布, 残 留応力分布の変化をそれぞれ Fig. 6, 7 中に示す. Fig. 6 より，疲労試験後において，TBF 鋼では，表面に近いほ ど硬さは大きく減少すること, および $\gamma_{\mathrm{R}}$ の体積率は疲労 変形後には少し減少することがわかる．上述の疲労試験 後の表面硬化層の硬さの減少 (疲労軟化) ${ }^{18)}$ は SNCM420 鋼でも同様に現れた．疲労試験後の表面硬化層の残留応
力は従来の報告 ${ }^{19)}$ と同様に減少したが，TBF 鋼におい てその減少量はかなり小さかった.

\section{$3 \cdot 5$ 疲労き裂の発生と進展挙動}

Fig. 10 に FPP 処理を施していない $\mathrm{TBF}$ 鋼の平滑材で 発生した疲労き裂のSEM 像を示寸。疲労き裂は主に母 相組織のすべり帯，もしくは母相／第２相界面で発生し た。また，MA 相と思われる部分で成長が妨害された疲 労き裂が観察された。なお，FPP 処理を施した TBF 鋼に

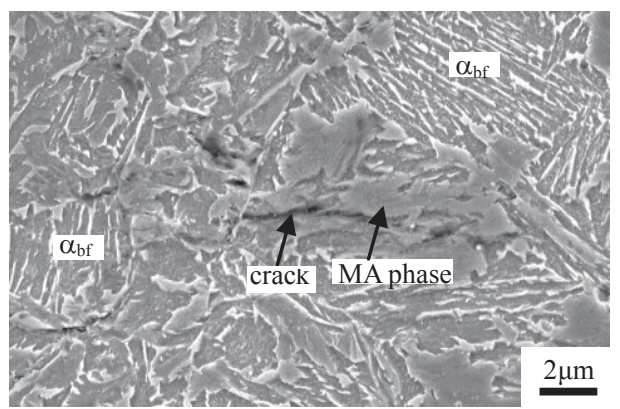

Fig. 10 SEM image of the surface of a smooth specimen of unpeened TBF steel $\left(\sigma_{\mathrm{a}}=682 \mathrm{MPa}, N_{\mathrm{f}}=1.14 \times 10^{5}\right.$ cycles $) . \alpha_{\mathrm{bf}}$ : bainitic ferrite

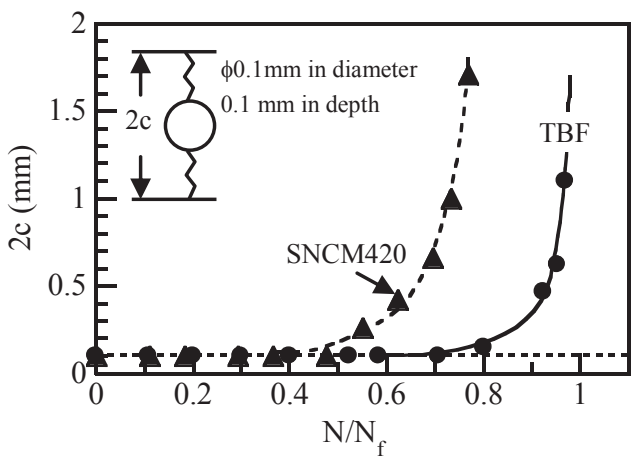

Fig. 11 Variations in crack length $(2 c)$ as a function of the cycle ratio $\left(N / N_{\mathrm{f}} ; N_{\mathrm{f}}\right.$ : number of cycles to fracture $)$ in $\operatorname{TBF}(\bullet)$ and SNCM420 ( $\Delta$ ) steels subjected to fine particle peening. $\sigma_{\mathrm{a}}=830$ $\mathrm{MPa}$.

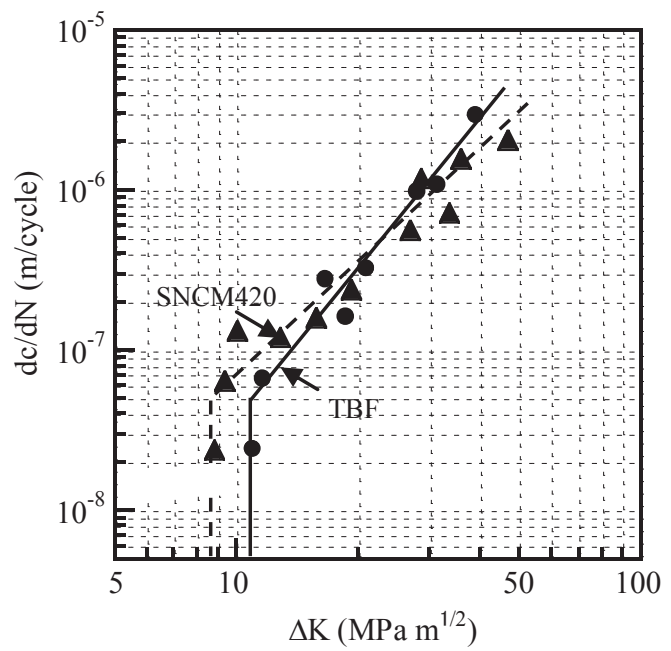

Fig. 12 Relationship between surface crack growth rate $(\mathrm{d} c / \mathrm{d} N)$ and stress intensity factor range $(\Delta K)$ in TBF $(\bullet)$ and SNCM420 ( $\mathbf{\Delta})$ steels subjected to fine particle peening. 
おいて, 疲労き裂の発生場所を観察することは困難であ った.

Fig. 11 に FPP 処理を施した各鋼の繰返し数比 $\left(N / N_{\mathrm{f}}\right.$; $N_{\mathrm{f}}$ は破断サイクル数）と微小穴を含む表面き裂長さ $(2 c)$ の関係を示す．SNCM420 鋼に比べ，TBF 鋼ではき裂の 発生寿命が長いことがわかる。

Fig. 12 に, Fig. 11 の結果から求めた FPP 処理を施した 各鋼のき裂進展速度 $\mathrm{d} c / \mathrm{d} N$ と応力拡大係数範囲 $\Delta K$ の関 係を示す。ここで，深さ方向におけるき裂前縁の応力拡 大係数範囲 $\Delta K$ は，白鳥ら ${ }^{20)}$ の解析により得られた補正 係数を用いて算出しているが，残留応力の影響は考慮し ていない. $\mathrm{TBF}$ 鋼では $\Delta K \leqq 25 \mathrm{MPa} \mathrm{m}^{1 / 2}$ の領域におい て，SNCM420鋼よりもき裂進展速度は遅かった.また， 応力振幅漸減法によって得られた下限界応力拡大係数 範囲 $\Delta K_{\text {th }}$ は $\mathrm{TBF}$ 鋼で $11.0 \mathrm{MPa} \mathrm{m}^{1 / 2}, \mathrm{SNCM} 420$ 鋼で 8.8 $\mathrm{MPa} \mathrm{m}^{1 / 2}$ であり, TBF 鋼の值は SNCM420 鋼に比較して 25\%高かった。

\section{4 考察}

\section{$4 \cdot 1$ FPP 処理を施した TBF 鋼の疲労限の推定式}

先の報告 ${ }^{12)}$ によれば，TBF 鋼の表面に FPP 処理を施 したとき，主に以下の組織変化を生ずる.

(1) 著しく大きな塑性変形による母相組織の転位密度の 増加 ${ }^{21)}$

(2) $\gamma_{\mathrm{R}}$ のひずみ誘起マルテンサイト変態 ${ }^{4)}$

上記の(1)と(2)はともに表面層の硬さを増加させるとと もに，表面層に圧縮の残留応力を付与寸る ${ }^{12), 22) . ~}$

本研究の表面硬化層の硬さ分布と残留応力分布は，平 板で測定した名取ら ${ }^{12)}$ と同様な結果が得られたので，以

Table 6 Surface layer properties after fine particle peening in TBF and SNCM420 steels.

\begin{tabular}{c|c|ccc}
\hline Steel & $H V_{S}$ & $\sigma_{Y, \text { est }}$ & $\sigma_{X, \max }$ & $\sigma_{Y, \text { est }}+\sigma_{X a, \max }$ \\
\hline TBF & 448 & 1391 & 775 & 2166 \\
\hline SNCM420 & 414 & 1286 & 628 & 1914 \\
\hline
\end{tabular}

$H V_{\mathrm{S}}$ : Vickers hardness of the surface after fine particle peening, $\sigma_{\mathrm{Y}, \text { est }}$, $\sigma_{\mathrm{X} a \text {, max }}(\mathrm{MPa})$ : estimated yield stress and maximum compressive residual stress after fine particle peening, respectively.

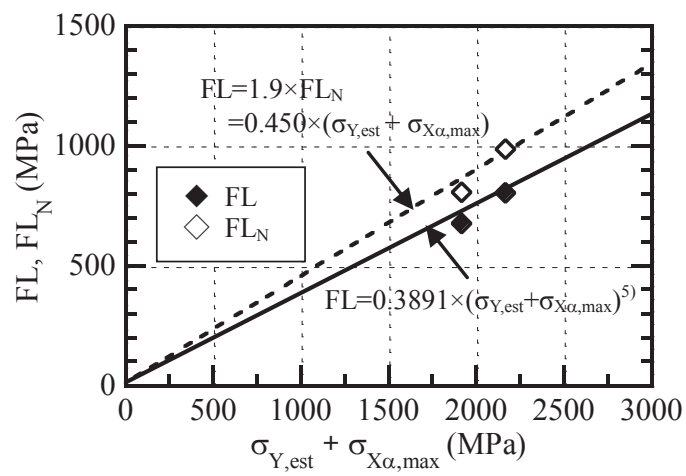

Fig. 13 Relationship between rotating fatigue limits $\left(F L, F L_{\mathrm{N}}\right)$ and the sum of yield stress and maximum compressive residual stress $\left(\sigma_{\mathrm{Y}, \text { sst }}+\sigma_{\mathrm{X} \text {, max }}\right)$ of smooth and notched specimens in TBF and SNCM420 steels.
下では FPP 処理による平滑材と切欠き材の疲労限を上 記の(1)と(2)と関連づけてみる.

一般に, 疲労破壊過程の Stage I の抵抗因子は主に降伏 応力（または硬さ）であり, Stage II のそれは主に圧縮残 留応力である ${ }^{5)}$ と考えられている. 松井ら ${ }^{5}$ は浸炭処理 を施した SCM $822 \mathrm{H}$ 鋼を用いて, 回転曲げ疲労試験（応 力比 $R=-1 ＼mathrm{~ の 疲 労 限 に 及 ほ ゙ す シ ョ ッ ト ヒ ゚ ー ニ ン ク ゙ の ~}$ 影響を調査し, 回転曲げ疲労限 $F L$ （切欠き材の疲労限 に応力集中係数を乗じた值）と表面硬さから推定した降 伏応力と最大圧縮残留応力の和 $\left(\sigma_{\mathrm{Y}, \mathrm{est}}+\sigma_{\mathrm{X} \alpha, \max }\right)$ との間 には次式の直線関係があることを報告している。

$$
F L=0.3891 \times\left(\sigma_{\mathrm{Y}, \mathrm{est}}+\sigma_{\mathrm{X} \alpha, \max }\right)
$$

この場合， $\sigma_{\mathrm{Y}, \text { est }}(\mathrm{MPa})$ を降伏比 $(Y R)$ とショットピー ニング後の表面直下 (深さ $20 \mu \mathrm{m})$ のビッカース硬さ $\left(H V_{\mathrm{S}}\right)$ を用いて次式から推定している.

$$
\sigma_{\mathrm{Y}, \text { est }}=H V_{\mathrm{S}} / 3 \times 9.80665 \times Y R=3.105 H V
$$

松井ら ${ }^{5)}$ は，(5)式において降伏比を0.95 としている.

Fig. 13 に本研究の FPP 処理後の TBF 鋼と SNCM420 鋼の平滑材と切欠き材の回転曲げ疲労限 $\left(F L, F L_{\mathrm{N}}\right)$ と $\sigma_{\mathrm{Y}, \text { est }}+\sigma_{\mathrm{X} \alpha, \max }$ の関係を示す. なお, $\sigma_{\mathrm{Y}, \mathrm{est}}+\sigma_{\mathrm{X} \alpha, \max }$ と $F L, F L_{\mathrm{N}}$ の值にはそれぞれ Table 6, Table 5 に示す值を用いた。計 算に際し，HVs としては深さ $10 \mu \mathrm{m}$ での硬さ，降伏比と しては松井ら ${ }^{5)}$ と同様に 0.95 を代入した。また，切欠き 材に対しては疲労限に応力集中係数（1.9）を乗じた值を 用いた. Fig. 13 中に示されるように，平滑材では浸炭を 施さない場合でも，(2)式で示される松井ら ${ }^{5)}$ の平滑材で の結果とほぼ等しい関係が得られた。このことは，本研 究の TBF 鋼でも上記の(1), (2)に起因する表面硬さの増 加量（降伏応力の増加量）と圧縮残留応力の増加量によ って疲労限が決定されることを示唆している. なお, Fig. 13 中には, $\mathrm{TBF}$ 鋼と SNCM420 鋼の切欠き材の疲労限 と $\sigma_{\mathrm{Y}, \mathrm{est}}+\sigma_{\mathrm{X} \alpha, \max }$ の関係も示すが，この場合は松井ら ${ }^{5)}$ の 関係より直線の傾きは大きくなった。

Fig. 7 において, 疲労試験後の両鋼の表面硬化層の圧 縮残留応力の絶対值は両鋼で減少した. 一般に, 応力比 が正の場合には疲労試験後も圧縮残留応力はほとんど 低下しないことが示されている ${ }^{23)}$. しかし，越宗ら ${ }^{24)}$ によると, 応力比が負の場合には, 負荷応力と圧縮残留 応力の和が降伏応力を超えると, 圧縮側の負荷で降伏し, 圧縮残留応力が減衰することが指摘されている. 本研究 では応力比は $R=-1$ であり, 負荷応力と圧縮残留応力 の和が降伏応力を超えているため，この事実と一致する. 本実験で注目すべき点は, TBF 鋼では疲労変形後の表面 硬化層の圧縮残留応力の低下量が SNCM420 鋼に比較し て小さい点である.この結果は $\mathrm{TBF}$ 鋼の疲労限の増加に 貢献していると考えられるが，詳細については今後の検 討課題としたい。 


\section{$4 \cdot 2$ TBF 鋼のき裂発生・進展挙動への $\gamma_{\mathrm{R}}$ の役割}

Fig. 11，12 において，TBF 鋼では，SNCM420 鋼に比 べて疲労き裂の発生は抑制され，き裂進展速度も遅くな った。このような挙動には, 表面硬化層の高い圧縮残留 応力, 疲労軟化や $\gamma_{\mathrm{R}}$ のひずみ誘起変態が影響することが 予想される. そこで, 以下では， $\gamma_{R}$ のひずみ誘起変態に 着目して, き裂発生・進展挙動への $\gamma_{\mathrm{R}}$ の役割について考 察する。

$\mathrm{Knott}^{25)}$ によれば, き裂先端の塑性域寸法 $\left(w_{\mathrm{Y}}\right)$ は次式 で見積もられる。

$$
w_{\mathrm{Y}}=K^{2} /\left(3 \pi Y S^{2}\right)
$$

ここで, $K$ は $\sigma(\pi c)^{1 / 2}(\sigma$ :負荷応力, $\mathrm{c}$ :き裂長さ $)$ で定義 される応力拡大係数である.いま, FPP 処理を施した TBF 鋼の切欠き材を疲労限の応力振幅で疲労変形した時, $\gamma_{\mathrm{R}}$ のほとんどが変態してしまっている表面では, 未変態 $\gamma_{R}$ のひずみ誘起変態の効果はほとんど見込めない.しかし 表面から 1～2 結晶粒の内部 $(10 \sim 20 \mu \mathrm{m})$ では $\gamma_{\mathrm{R}}$ の半分 以上が残存しているので， $\gamma_{R}$ のひずみ誘起変態の効果は 期待できる. 疲労き裂が 1〜2 結晶粒長さの時の疲労き 裂先端部での塑性域寸法を(6)式から計算すると， $w_{\mathrm{Y}}=$ 2.2〜4.4 $\mu \mathrm{m}$ であった。この計算の際，(6)式の $Y S$ には Table 4 の降伏応力と引張強さの平均值 $((Y S+T S) / 2=1210$ $\mathrm{MPa}$ )を用い, $\sigma$ には Table 5 の切欠き材の疲労限に応力 集中係数を乗じた值 $(520 \mathrm{MPa} \times 1.9)$ を用いた。同様な条 件で $\mathrm{TBF}$ 鋼の平滑材について計算すると， $w_{\mathrm{Y}}=1.5 \sim 3.0$ $\mu \mathrm{m}$ であった。 Fig. 14 に塑性域寸法と微細組織サイズの 関係を模式的に示す. TBF 鋼の FPP 処理後の切欠き材と 平滑材の塑性域サイズは $\gamma_{\mathrm{R}}$ や MA 相の間隔（1.5〜3.5 $\mu \mathrm{m} ）$ 之同程度か少し大きく，き裂先端の塑性域内に十分 な量の未変態 $\gamma_{\mathrm{R}}$ が存在し, マルテンサイトへひずみ誘起 変態する確率が高くなることが予想される，以上より， $\mathrm{FPP}$ 処理を施した $\mathrm{TBF}$ 鋼の平滑材と切欠き材のき裂発生 と進展挙動に及ぼす $\gamma_{\mathrm{R}}$ の役割は以下のようにまとめら れる。

(i) 表面硬化層に存在する既にひずみ誘起変態した $\gamma_{\mathrm{R}}$ は, 硬さと圧縮残留応力を高めて疲労き裂の発生を抑制 するとともに，硬質相（MA 相，硬質マルテンサイト $\left(\alpha_{\mathrm{m}}{ }^{*}\right)$ 相）として疲労き裂の進展を抑制する（Fig. 10 参照).

(ii）表面硬化層に存在する多量の未変態の $\gamma_{\mathrm{R}}$ は, ひずみ 誘起マルテンサイト変態を通して, 疲労き裂先端の 局所的応力集中を塑性的に緩和し，疲労き裂の進展 を抑制する。

このほか，TBF 鋼においては，未変態 $\gamma_{\mathrm{R}}$ のひずみ誘起 変態時の体積膨張が疲労き裂閉口挙動に影響すると考 えられるが，この点については今後の検討課題としたい。 本研究の $\mathrm{TBF}$ 鋼の切欠き材では, 平滑材と同様に FPP 処理によって疲労限の増加が顕著に現れた。これは塑性 域が拘束される切欠き材ほど $\gamma_{\mathrm{R}}$ のひずみ誘起変態時の
塑性緩和効果がより顕著に現れ，3 軸塑性切欠き拘束 ${ }^{26)}$

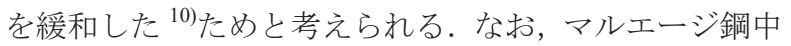
に存在する逆変態 $\gamma$ でも, き裂発生とき裂進展を抑制す る効果が報告されている ${ }^{18)}$.

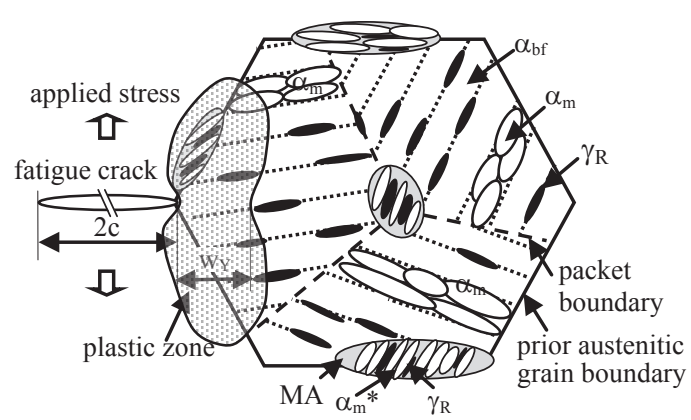

Fig. 14 Illustration of the plastic zone size $\left(w_{\mathrm{Y}}\right)$ at a crack tip and distribution of retained austenite and MA phases in TBF steel, in which $\alpha_{\mathrm{m}}, \alpha_{\mathrm{m}}{ }^{*}, \alpha_{\mathrm{bf}}$, and $\gamma_{\mathrm{R}}$ represent soft wide lath-martensite, hard narrow lath-martensite, bainitic ferrite and retained austenite, respectively.

\section{5 結 言}

本研究では, $\mathrm{TBF}$ 鋼の平滑材と切久き材の疲労強度特 性に及ぼす FPP 処理の影響を調查した。得られた結果を 以下に示寸。

(1) TBF 鋼に対し，FPP 処理は，SNCM420 鋼に比較して 表面硬化層の硬さと圧縮残留応力を大きく増加させた。

(2) また, $\mathrm{TBF}$ 鋼の平滑材と切欠き材の疲労限と疲労寿 命は FPP 処理によって大きく増加した。 その疲労限の増 加率は切欠き材においてより大きかった。

(3) 疲労き裂の発生と進展挙動の観察より, $25 \mathrm{MPa} \mathrm{m}^{1 / 2}$ 以下の応力拡大係数範囲において, FPP 処理を施した $\mathrm{TBF}$ 鋼は SNCM420 鋼よりもき裂進展速度は遅かった。 また，下限界応力拡大係数範囲 $\Delta K_{\mathrm{th}}$ は $25 \%$ 高かった.

（4） TBF 鋼の疲労限と, 表面硬さから推定した降伏応力 と最大圧縮残留応力の和 $\left(\sigma_{\mathrm{Y}, \text { est }}+\sigma_{\mathrm{X} \alpha \text {, max }}\right)$ との間には直 線関係が認められた。

(5) このような FPP 処理を施したときの TBF 鋼の高い疲 労限と長い疲労寿命は, 主に表面硬化層の準安定 $\gamma_{\mathrm{R}}$ のひ ずみ誘起マルテンサイト変態によって生じた(1)高い表 面硬さ, (2)高い圧縮残留応力と (3)塑性緩和により, き裂 の発生と進展が抑制されたためと考えられる.

本研究の一部は文部科学省科学研究費補助金 (基盤研 究 B，No.2013-2528926）を用いて行われた。ここに，深 謝致します。

\section{参 考 文 献}

1) M. Komori, "Leading technology of Japan on gears and motion \& power transmissions", The Japan Society for Precision Engineering, Vol.73, pp.19-22 (2007).

2) S. Wang, Y. Li, M. Yao and R. Wang, "Compressive residual stress introduced by shot peening", Journal of Materials Processing Technology, Vol.73, pp.64-73 (1998). 
3) B.A. Shaw, C. Aylott, P. O'Hara and K. Brimble, "The role of residual stress on the fatigue strength of high performance gearing", International Journal of Fatigue, Vol.25, pp.1279-1283 (2003).

4) H. Eto, K. Matsui, Y. Jin and K. Ando, "Influence of retained austenite, strain-induced martensite and pre-loaded stress upon compressive residual stress with shot peening method", The Japan Society of Mechanical Engineers, Series A, Vol.69, pp.733-740 (2003).

5) K. Matsui, M. Koshimune, K. Takahashi and K. Ando, "Influence of shot peening method on rotating bending fatigue limit for high strength steel", Transactions of Japan Society of Spring Engineers, Vol.55, pp.7-12 (2010).

6) M. Yoshizaki, "Effect of fine particle bombarding process on tooth surface properties and tooth surface strength of carburized gears ( $1^{\text {st }}$ report, Effect on tooth surface properties)", Transactions of the Japan Society of Mechanical Engineers, Series C, Vol.73, pp.1923-1930 (2007).

7) M. Kato, Y. Matsumura, R. Ishikawa, Y. Kobayashi and S. Ujihashi, "Influence of shot peening condition on the fatigue strength of the carburizing steel", Denki-Seiko, Vol.79, pp.69-76 (2008).

8) S. Takagi, M. Kumagai, Y. Ito, S. Onuma and E. Shimodaira, "Surface nanocrystalization of carburized steel JIS-SCr420 by fine particle peening", Tetsu-to-Hagane, Vol.92, pp.318-326 (2006).

9) W. Nakao, M. Koshimune, K. Matsui and K. Ando, "Influence of phase transformation of retained austenite on fatigue limit", Transactions of Japan Society of Spring Engineers, Vol.53, pp.9-12 (2008).

10) N. Yoshikawa, J. Kobayashi and K. Sugimoto, "Notch fatigue properties of advanced TRIP-aided bainitic ferrite steels", Metallurgical and Materials Transactions A, Vol.43A, pp.4129-4136 (2012).

11) S. Song, K. Sugimoto, M. Kobayashi, H. Matsubara and T. Kashima, "Impact properties of low alloy TRIP steels”, Tetsu-to-Hagane, Vol.86, pp.563-569 (2000).

12) N. Natori, S. Song and K. Sugimoto, "The effects of fine particle peening on surface residual stress of a TRIP-aided bainitic ferrite steel", Journal of the Society of Materials Science, Japan, Vol.63, No.9, pp.662-668 (2014).

13) H. Maruyama, "X-ray measurement of retained austenite", Journal of Japan Society of Heat Treatment, Vol.17, pp.198-204 (1977).

14) D.J. Dyson and B. Holmes, "Effect of alloying additions on the lattice parameter of austenite", Journal of The Iron and Steel Institute, Vol.208, pp.469-474 (1970).

15) The Society of Materials Science, Japan, "Standard measurement method of X-ray stress", The Society of Materials Science, Japan, Kyoto, p. 3 (1977).

16) H. Nakazawa and H. Honma, "Fatigue strength of metals", Yokendo, Japan, Tokyo, p.25 (1982).

17) G. E. Dieter, "Mechanical Metallurgy (SI Metric Edition)”, McGraw-Hill Book Co., London, p.403 (1988).
18) T. Nagano, N. Kawagoishi, M. Moriyama, H. Nishitani and E. Kondo, "Influence of reversion austenite on notch sensitivity of maraging steel", The Japan Society of Mechanical Engineers, Series A, Vol.68, pp.1724-1729 (2002).

19) H. Dalaei, B. Karlsson and L-E. Svensson, "Stability of shot peening induced residual stresses and their influence on fatigue lifetime", Materials Science and Engineering A, Vol.528, pp.1008-1015 (2011).

20) M. Shiratori, T. Miyoshi, Y. Sakai and G. Zhang, "Analysis of stress intensity factors for surface stress (3rd report, Analysis and application of influence coefficients for round bars with a semielliptical surface crack)", The Japan Society of Mechanical Engineers, Series A, Vol.53, pp.779-785 (1987).

21) M. Umemoto, "Nanocrystalization of steels by sever plastic deformation", Materials Transactions, Vol.44, pp.1900-1911 (2003).

22) T. Sakaki, K. Sugimoto and T. Fukuzato, "Role of internal stress for continuous yielding of dual-phase steels", Acta Metallurgica, Vol.31, pp. 1737-1746 (1983).

23) K. Matsui, H. Eto, K. Yukitake, Y. Misaka and K. Ando, "Increase in fatigue limit of gears by compound surface refining using vacuum carburizing, contour induction hardening and double shot peening", The Japan Society of Mechanical Engineers, Series A, Vol.66, pp.1878-1885 (2000).

24) M. Koshimune, K. Matsui, K. Takahashi, W. Nakao and K. Ando, "Influence of hardness and residual stress on fatigue limit for high strength steel", Transactions of Japan Society of Spring Engineers, Vol.54, pp.19-26 (2009).

25) J.F. Knott, Fundamentals of Fracture Mechanics, Baifukan, Tokyo, p.127 (1977).

26) T. Majima, M. Anzai and H. Nakazawa, "Notch tensile strength of ductile materials", Transactions of the Japan Society of Mechanical Engineers, Series A, Vol.52,_pp.1171-1176 (1986). 